\title{
The Effectiveness of Skimming and Scanning Techniques in Improving Students' Reading Comprehension of Grade Eleventh Students in SMA Negeri 1 Tana Toraja
}

\author{
Yanti Mambua ${ }^{1}$, Konder Manurung ${ }^{2}$, Aminah $^{3}$ \\ ${ }^{1}$ Student of Master of English Education Tadulako University, Palu, Indonesia. \\ ${ }^{2}$ Lecturer of Master of English Education Tadulako University, Palu, Indonesia. \\ ${ }^{3}$ Lecturer of Master of English Education Tadulako University, Palu, Indonesia.
}

\section{ARTICLE INFO}

AIJ use only:

Received date : 10 June 2020

Revised date : 30 June 2020

Accepted date : 15 July 2020

Keywords:

Reading Comprehension

Skimming and Scanning

\section{A B S T R A C T}

This research aims to prove that the use of Skimming and Scanning techniques are effective in improving reading comprehension of grade-eleventh students in SMA Negeri 1 Tana Toraja. The method used in this research was true-experimental design random assignment pretest-posttest control group. The samples of this research were selected from the population of grade eleventh students of SMA Negeri 1 Tana Toraja by using random sampling technique. The instruments of data collection were observation checklist, questionnaire items and tests. The data were analyzed by using t-test statistical and descriptive methods. Based on the analysis, the result score of experimental class is 80.27 and the control class is 67.02. By applying the level of significance 0.05 and degree of freedom (df) 48, the t-counted value (4.3) is greater than t-table value (2013). Furthermore, based on the result of effectiveness indicators the score shows $83 \%$. It means that the techniques are effective. In other words, applying skimming and scanning techniques are effective in improving students' reading comprehension of the grade eleventh students of SMA Negeri 1 Tana Toraja

\section{INTRODUCTION}

The Department of National Education has made English as a compulsory subject and positioned it as the first foreign language to be taught at school based curriculum. It is regulated on the Indonesian Government Number 20, 2003 about National Education System and the Law Government Number 19, 2005 about National

\footnotetext{
* Corresponding author.

E-mail address: yantimambua01@gmail.com

Article with open access under license
}

Education Standard which is revised by Government Regulation Number 32, 2013. It has been evaluated from time to time for preparing students to meet the challenges in the work-force. English is included as one of the subjects examined in the National Examination. However, the skills for English lesson included on National Examination are only reading, listening and writing. One of the language skills that will be focused in this study is reading skill. Actually, it is a crucial skill. It is a complex activity which needs times to read more effectively. The indicators in Curriculum 2013 related to reading reading conpetence are as follows. First, to identify 
the general information about the text. Second, to identify the main idea explicitly. Third, to identify the main idea implicitly. Fourth, to get detail information about the text. The last, to infer words, phrases, and sentences meaning based on the context.

In syllabus design, the competence standard that belongs to reading skill is that the students have to comprehend the meaning of functional text. The teachers must consider seriously about a proper strategy to teach reading competence. For instance, a strategy which can assist students to improve their reading skill as one of the four language skills. For example, the form of material that is presented in the National Examination, UN (Ujian Nasional), is frequently a text or reading passage. The students have to read English texts with a limitation time to understand and find related information to answer the questions. To overcome this problem, the teacher should use appropriate technique to improve students' reading skill to be better. The readers do not need to read every word in the text to be efficient readers

(Wallace, 2004) It means that the readers only need to find the information they need from the text without reading the whole text in order to make them able to manage their time effectively.

From the preliminary observation and informal interview with the English teacher and some of grade-eleventh students of SMA Negeri 1 Tana Toraja, the researcher found problems in the English teaching and learning process. The students have low skills in comprehending English texts and have low participation in teaching and learning process. The most problem occurred in the classroom is the limitation time for the students to read. It happens because the common activity in the classroom is the combination between some skills and components of English. The result is the students lose their time because they are busy with difficult words and read every word in the text. When the students do the exercise in the text, they find it difficult to answer the questions because they do not know the content of the text and when they face the exam or National Examination there is a limitation time, so they need to get used to think and comprehend the text. Consequently, they spent much time to answer the comprehension question related to the text because they do not know what technique that can be used to get the information quickly from the text.

The researcher also found the students who mostly didn't understand how to answer the questions in reading comprehension level such as literal, inferential and critical reading comprehension quickly. Therefore, in this case, the researcher wants to make the student's literal, inferential, and critical reading comprehension level improve, so that they are able to find the information that explicitly stated in the text, to interpret, to analyze and to review the text with their prior knowledge and defend their point of view about the text quickly.

The purposes of this study are:

1. To find out whether the implementation of skimming and scanning techniques can improve reading comprehension of grade eleventh students of SMA Negeri 1 Tana Toraja.

2. To find out how effective skimming and scanning techniques in improving reading comprehension of grade-eleventh students in SMA Negeri 1 Tana Toraja.

\section{THEORY/CALCULATION (if any)}

Skimming and scanning techniques help to improve the students' speed reading and their abilities of comprehension (Abdelrahman \& Bsharah, 2014). Skimming and scanning are the effective techniques that are useful to enhance the students' reading comprehension. (Grabe \& Stoller, 2002) states that skimming is a specialized type of reading in which the reader reads quickly for general understanding of the text and for the gist of the passage. (Brown, 2003) says scanning is the process of quickly searching for particular piece or pieces of information in a text. The purpose of scanning is to extract specific information without reading the whole text. Skimming and scanning techniques are required in helping students in comprehending a text, getting general idea, detailed information and other reading tasks. Skimming and scanning techniques are also intended to help students in overcoming the Senior High School curriculum tasks in Indonesia. Based on that explanation, the researcher concludes that these techniques are very useful for the students to avoid spending unnecessary time in reading and finding 
the specific or general information. To apply skimming and scanning techniques, they may become one of the reading improvement programs which can be applied by a teacher to assist the students to read various topics of reading materials. By applying these techniques, the students will be able to build their existing knowledge about the topic material of reading material in order to help them in comprehending the reading passage.

The teacher should be able to develop students' reading comprehension in which they can read the text effectively and efficiently. The readers should have a particular purpose in their mind before they interact with the text. He effective and efficient reading always purposeful and tends to focus mainly on the purpose of the activity and the purpose of reading. (Farstrup \& Samuels, 2002) stated that teachers should be aware and knowledgeable of many instructional methods and strategies available to promote students' reading comprehension and motivate their students towards reading, promote their interest and encouragement in reading one, develop their reading comprehension skills, and aid them in accomplishing reading comprehension tasks successfully. This is in line with (Manurung, 2012) who argues that there is a change of the role of a teacher from teaching to facilitating the learning process in order to motivate learners to learn. The purpose of reading also determines the appropriate technique to reading comprehension.

Skimming and scanning are two specific speeds reading techniques to help the readers to read effectively. It enables the readers to get information from a material very rapidly. These two techniques are similar in process but different in purpose. According to (Pappas \& Tepe, 2002), students need to use the strategies of skimming and scanning to determine if the information they have located is even relevant to their research or information need.

a. Skimming as well as scanning is a speed reading technique. Yet, they are not the same. These two strategies which have different purposes, eventhough both of them include getting the ideas of the text quickly. According to (Brown, 2004), skimming is the process of rapid coverage of reading matter to determine its gist or main idea. Meanwhile the purpose of skimming, according to (Mikulecky, S. B. \& Jeffries, 2004) is to get a general sense of a passage or book, not specific details. Furthermore, he claims that when we do skimming it means that we have a general question about the whole text first.

b. Scanning technique is defined as "quick reading", focusing on locating specific information (Macleod, n.d.). It means scanning is a technique of reading to look for detail or specific information based on the purpose of the readers, e.g. when the readers want to identify or look for the specific information (name, time, date, place, and initial).

The skimming and scanning task instructions for the students:

\section{Skimming}

1. Read the first few paragraphs, two or three middle paragraphs and the final two or three paragraphs of a piece trying to get a basic understanding of the information.

2. Some people refer to skim by reading the first and last sentence of each paragraph (i.e., the topic sentences and concluding sentences)

3. If there are pictures, charts or diagrams, a quick glance at them may help you to understand the main idea or point of view in the text.

4. Remember: you do not have to read every word when you skim.

5. Generally, move your eyes horizontally and quickly as you skim.

\section{Scanning}

1. Knowing your text well is important. Make a prediction about where in the text you might find a word, a date, a name or a fact.

2. Note how the information is arranged on page. Ask yourself, "Will headings, diagrams, boxed or highlighted information guide me? Is information arranged by alphabetical or numerically as it might be in a telephone book or glossary?"

3. Move your eyes vertically or diagonally down a page, letting them dart quickly from side to side, and keeping in mind the exact type of information that you want. Look for closely associated words that might steer you towards the detail for which you are looking. 
You have scanned successfully when you have found the information you were looking for.

\section{METHOBurnal of Social Science | Jsss.co.id 95}

This research used True-experimental research design. (Creswell, 2002) states Trueexperimental studies require random selection of subject and assignment of control and experimental groups. There are two groups involved in this research, the one is experimental and the other one is control class. The experimental class received new treatment by using skimming and scanning techniques and control class received conventional treatment.

The population of this research was the grade eleven students of SMA Negeri 1 Tana Toraja consists of 6 classes (Science) and 177 students. The sample was selected by using random sampling techniques. 50 students selected as a sample, 25 students in experimental class and 25 students in control class. The sample was randomly chosen by lottery.

In collecting the data the researcher used observation, questionnaire, and test. The researcher observed the condition of the students' atmosphere in the class during the teaching and learning process through skimming and scanning technique. It is used as the instrument of effectiveness of techniques applied. The objectives of distributing questionnaire are to get valid data regarding to the effectiveness of the skimming and scanning techniques, to make sure that the treatment has a benefit and to collect student's point of view and interest about the Implementation of the treatment. Last, the test covered pretest and posttest.

\section{Testing Hypothesis}

To know whether the hypothesis of the research was accepted or rejected, the researcher tested based on7034961397on. The criteria were if the $\mathrm{t}_{\text {-calculated }}$ is greater than $\mathrm{t}$-table value, the alternative hypothesis ( $\mathrm{Ha}$ ) is accepted and the null hypothesis (Ho) was rejected. It implied that the $\mathbf{7 0 3 4 9 6 1 3 9 7}$

The effectiveness of skimming and scanning techniques seen from student's activity (observation), students responds (questionnaire) and students learning outcomes (posttest)

Table 1

The Result of Effectiveness

\begin{tabular}{ccc}
\hline No & Scale & Classification \\
$\mathbf{1}$ & $\mathbf{8 1 - \mathbf { 1 0 0 \% }}$ & Effective \\
$\mathbf{2}$ & $\mathbf{6 1 - 8 0 \%}$ & Moderately Effective \\
$\mathbf{3}$ & $\mathbf{4 1 - 6 0 \%}$ & Slightly Effective \\
$\mathbf{4}$ & $\mathbf{0 - 4 0 \%}$ & Not Effective \\
\hline \multicolumn{2}{r}{ (Adopted from Riduwan, 2013) }
\end{tabular}

\section{RESULTS AND DISCUSSION}

The researcher observed the students activities during the treatment with the intention to catch all of them by moving from one student to another, one place to the next, or standing and typically at a distance that allow her to watch the entire class. The researcher taught the students with her eyes, ears, and mind opened to what is happening in the classroom. Watching and listening to students with curiosity and wonder who are they, what they know about the material, what they do during the activity and to ensure that the students understand the techniques applied. The observation covered all students' activities during the pre-, while-, and post-activities. It was found that students are motivated to read the text by using skimming and scanning techniques, do the exercises individually, worked cooperatively make a conclusion about the materials that they have learned. In teaching and learning process the students were active in asking question to the researcher's explanation about the material and techniques, active in sharing their ideas and discussed the task with the researcher.

\section{The Result of Questionnaire}

The questionnaire contained 10 items which were categorized into two major central points. They were students' previous learning of reading practice and their attitudes toward the influence of treatment on students' literal, inferential and critical reading level, while the second point was aimed at finding out the effects of the implementation of students' way of thinking by using skimming and scanning techniques.

The first item concerned with teacher previous technique in teaching reading. The result showed that almost all students (88\%) confirmed that they 
had never been taught with skimming and scanning techniques and only a few students (20\%) not sure that they had.

The second item was decided to concentrate on teacher's attitude of giving answer to the questions that followed of reading text after his students could not find the answer themselves. It indicated that there were 17 students (68\%) agreed that the teacher gave help while a few students $8(32 \%)$ he did not. The third item showed that almost all of the students 23 (92\%) confirmed they had experience difficulties in finding and comprehending the text quickly, while only $2(8 \%)$ students not sure. It can be said that the improvement of students' reading level after the application of the treatment was not affected by students' prior learning of reading practice.

The data gathered from the students' questionnaire in item 4 until 10 showed that $83 \%$ of students agree with the application of skimming and scanning techniques and it significantly activates, motivates, and give challenge to the students during reading class.

\section{The Result of Tests}

The pretest was administered measure the students' ability in literal, inferential and critical reading to both classes. After conducting the pretest, the researcher gave treatment to experimental class for six meetings while the control group was taught by using conventional teaching method by the English teacher. Then, after giving treatment the researcher conducted posttest to both classes. The researcher used the same formula to calculate the students' score on posttest of experimental group and control group.

Figure 1

Mean Score of Pretest and Posttest

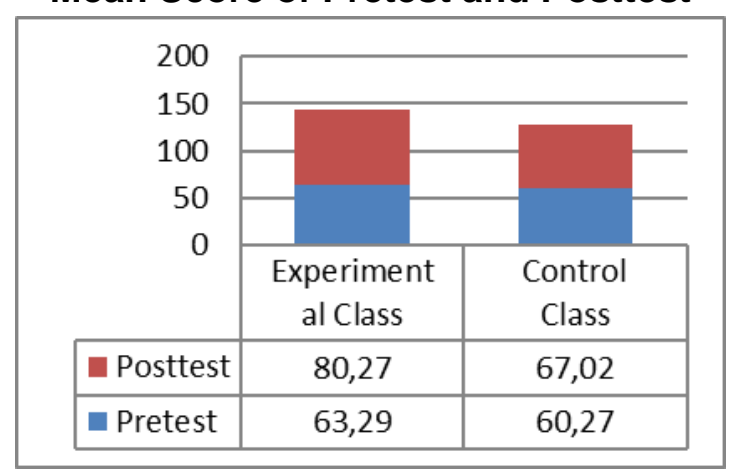

Based on the result, there was difference on students' reading skill of literal, inferential, and critical reading in experimental class after getting the treatment. After calculating the mean deviation of both groups, it shows that the mean deviation of experimental group was higher than control one. The mean deviation of experimental group on pretest and posttest was 16.96 while the mean deviation of control one was 8.64 Next, the researcher continued to find out the score of two groups using t-table to see whether there was significant difference between the means of two classes and the result showed that the $t$-counted was 4.3.

To achieve the $t_{\text {-table }}$ value, the researcher applied interpolation formula because the degree of freedom (df) $48(\mathrm{~N} 1+\mathrm{N} 2-2)$ with level of significant 0.05 cannot be found in the t-table list, the researcher applied the interpolation computation $\frac{a}{b} x c$ and found $\mathrm{t}_{\text {table }}$ value is 2.013 . The result of the test showed that $\mathrm{t}$-counted (4.3) was greater than $\mathrm{t}$ table (2.013). It means that researcher hypothesis was accepted. In other words, skimming and scanning techniques can improve student's literal, inferential and critical reading comprehension by the grade eleven students at SMA Negeri 1 Tana Toraja.

\section{The Improvement of Students' Reading Comprehension}

The reading comprehension test was aimed at measuring students' reading comprehension levels in literal, inferential, and critical by using skimming and scanning techniques.

Table 3

\begin{tabular}{|c|c|c|c|c|}
\hline Variable & t-test & Df & $\begin{array}{c}\text { t- } \\
\text { table }\end{array}$ & $\begin{array}{c}\text { Sig. (2 } \\
\text { tailed) }\end{array}$ \\
\hline Literal & 3.335 & 24 & 2.064 & 0.003 \\
\hline Inferential & 6.176 & 24 & 2.064 & 0.000 \\
\hline Critical & 3.869 & 24 & 2.064 & 0.001 \\
\hline
\end{tabular}

The result shows that there was significant difference between t-table and t-test in literal, inferential, and critical level after treatment by using skimming and scanning techniques. The statement was proved by the t-test value of literal comprehension (3.335), at the level of significance 0.05 and the degree of freedom $(\mathrm{N}-1)=(25-1)=$ 24 , or sig.(2-tailed) is smaller than $\alpha(0.003<0.05$, $\mathrm{df}=24)$. The t-test value of Inferential comprehension (6.176), and sig.(2-tailed) is smaller 
than $\alpha(0.000<0.05, \mathrm{df}=24)$. The t-test value of critical comprehension (3.869), and sig.(2-tailed) is smaller than $\alpha(0.001<0.05, \mathrm{df}=24)$.

\section{Analysis of the Effectiveness of Skimming and Scanning Techniques}

After analyzing the students learning

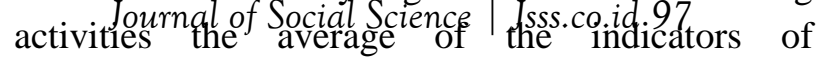
effectiveness (observation), responds (questionnaire), and final score (posttest) was $83 \%$. The result of data analysis showed that techniques were effective in giving a good impact on students' reading comprehension, especially to get the information quickly from the text.

\section{DISCUSSION}

After conducting the research, it can be concluded that there were two factors that have contributed in improving students' reading comprehension after applying skimming and scanning techniques. The first factor was the students act in response. During the treatment, it found that the students had high interest to study reading. It can be seen when the steps of skimming and scanning techniques were introduced at the beginning of the class, the students enthusiastically asked about the topics. When the techniques were implemented, the students were persuading to skipping some words that would not harm their understanding of the texts. After a few practice in every meeting on how to determined key words and phrases that could help them comprehend the text efficiently, they became more aware of the tips and tricks in answering the reading comprehension test by using skimming and scanning techniques. When they are invited to skim and scan the narrative text, they were excitedly did it. The students are asked to read the first text in order to get the general or main idea of it. To stimulate the students to read they were told words such as "quickly, quickly, do you know what the general idea of the text is? Where did story happen? Who is the main character?" The students seemed to be motivated to read faster, and after half a minute they had the information of the text. It indicated that the students were active in the teaching and learning process. The students are also interested in applying the steps of these techniques when reading in class and answer the questions based on the text during the treatment. This situation indicated that the students understood the lesson and enjoyed the teaching and learning process because they were facilitate, motivated, and stimulate in the reading process by using these two techniques

The second factor was the advantages of the techniques. The steps of skimming and scanning techniques helped the students to read efficiently. The techniques assist the students to make predictions on the purpose of the texts, the main topic and conceivably some supporting ideas rapidly. The students do not waste much time in understanding and obtaining information from the text. During the treatment the students were enthusiastically. They were able to tell all the details about the passage, their knowledge about the text can be said to be profound. The information extracted from the process of skimming and scanning techniques was enough to give a simple and accurate answer to the questions from the reading texts; as an outcome they were able to explain the answer in more detail. The students were trained how to use these techniques effectively and appropriately through applying some explicit instructions such as: make predictions before begin to read, guess the meaning of the text which surrounds it, select the keywords, predict the purposes of the text as well as identify the gist of the text, give feedback, provide friendly-explanation, and guidance. The implementation of the skimming and scanning techniques was also found during the treatment. Despite these techniques can save time in answering questions from reading texts, the students are required to be in the state of high concentration in using these techniques. If they are unfocused, they end up and not understanding the text at all. This was found in this current research; when students are unfocused, even just a little bit, they ended up reread the entire text to understand it. The classroom situation needs to be controlled with great deal to overcome this problem. The students who were noisy or were distracting their friends had to be swiftly stopped and handled to get them back on tract. The students were actively guided and motivated both individual with particular difficulties and the whole group if general difficulties arise and actively observed to make sure that the students are using the steps of the techniques correctly. 


\section{CONCLUSION}

Having discussed and analyzed the data in the preceeding chapter, the researcher concludes that

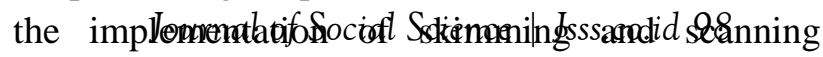
techniques significantly improves the students' reading comprehension of grade-eleventh students of SMA Negeri 1 Tana Toraja. The data gathered from the indicator of effectiveness show that the skimming and scanning techniques are effective in improving students reading comprehension.

\section{REFERENCES}

1. Abdelrahman, Mahmoud Sulaiman Hamad Bani, \& Bsharah, Muwafaq Saleem. (2014). The Effect of Speed Reading Strategies on Developing Reading Comprehension among the 2nd Secondary Students in English Language. English Language Teaching, 7(6), 168-174.

2. Brown, H. .. (2004). Language Assessment Principles and Classroom Practices. New York: Pearson Education, Ltd.

3. Brown, H. D. (2003). Language Assessment Principles and Classroom Practices. New Jersey: Prentice Hall.

4. Creswell, John W. (2002). Educational research: Planning, conducting, and evaluating quantitative. Prentice Hall Upper Saddle River, NJ.

5. Kementrian Pendidikan \&. Kebudayaan (Ministry of Education and Culture). (2013). Laporan Capaian Kompetensi Kurikulum 2013. Jakarta: Badan Standar Nasional Pendidikan.

6. Kementrian Pendidikan dan Kebudayan, Kementrian Pendidikan. (2013). Laporan Capaian Kompetensi Kurikulum 2013. Jakarta: Badan Standar Nasional Pendidikan.

7. Departemen Pendidikan Nasional (Ministry of National Education). (2003). Undang-undang Nomor 20 tahun 2003 tentang Sistem Pendidikan Nasional. Jakarta: Depertemen Pendidikan Nasional.

8. Departemen Pendidikan Nasional (Ministry of National Education). (2005). Peraturan Pemerintah Republik Indonesia Nomor 19 tahun 2005 tentang Standar Nasional Pendidikan. Jakarta: Depertemen Pendidikan Nasional.

9. Farstrup, Alan E., \& Samuels, S. Jay. (2002). What research has to say about reading instruction. ERIC.

10. Grabe, William, \& Stoller, F. (2002). Teaching and research reading. Harlow, UK: Longman.

11. Macleod, M. (n.d.). Types of Reading.

12. Manurung, Konder. (2012). Creative teachers and effective teaching strategies that motivates learners to learn. Indonesian Journal of Science Education, 2(1), 1-8.

13. Mikulecky, S. B. \& Jeffries, L. (2004). More Reading Power. New York: Pearson Education, Ltd.

14. Pappas, Marjorie, \& Tepe, Ann E. (2002). Pathways to knowledge and inquiry learning. Libraries Unlimited.

15. Wallace, Michael J. (2004). Study Skills in English Student's Book: A Course in Reading Skills for Academic Purposes. Cambridge University Press. 
Journal of Social Science 
